\title{
Molecular Characterization of Some Amylolytic Srains of Bacteria Isolated from Peels and Soils from Two Cassava Dumpsites
}

\author{
A. D. Victor Ayansina ${ }^{1 *}$, A. Olasoji Adelaja ${ }^{1}$, John Baba ${ }^{2}$ \\ ${ }^{1}$ Department of Biological Sciences, Bowen University, Iwo, Nigeria \\ ${ }^{2}$ Department of Microbiology, Ibrahim Badamasi Babangida University, Lapai, Nigeria \\ Email: *ayandvt@yahoo.com, *dayo.ayansina@bowenuniversity.edu.ng, demdelaj@yahoo.com, babajohn200133@yahoo.co.uk
}

How to cite this paper: Ayansina, A.D.V., Adelaja, A.O. and Baba, J. (2019) Molecular Characterization of Some Amylolytic Srains of Bacteria Isolated from Peels and Soils from Two Cassava Dumpsites. Open Journal of Applied Sciences, 9, 1-9.

https://doi.org/10.4236/ojapps.2019.91001

Received: October 5, 2018

Accepted: January 11, 2019

Published: January 14, 2019

Copyright $\odot 2019$ by author(s) and Scientific Research Publishing Inc. This work is licensed under the Creative Commons Attribution International License (CC BY 4.0).

http://creativecommons.org/licenses/by/4.0/

\begin{abstract}
Samples of peels and soils from cassava waste sites were collected from cassava processing factory in Oyo town, Oyo State and also a dumpsite in Alaya village, Aiyedire local government, Osun State, Nigeria. Bacterial isolation was carried out using the pour plate method to obtain amylolytic bacterial species capable of hydrolyzing starch. Fourteen bacterial isolates that were most responsive to starch hydrolysis were selected from both sampling sites for molecular investigations. DNA of the isolates was extracted and subjected to a cocktail mix and condition for PCR which was purified using two universal primers and afterwards the PCR product was used for the polymorphism through electrophoresis. Bacterial isolates were identified based on their genetic sequences and results showed Bacillus subtilis (21.44\%) to be the most frequently occurring specie. There was the prevalence of two similar strains Bacillus subtilis MML2483 and B. subtilis MML2411 which was isolated from the different sampling sites. Some other bacterial strains included Bacillus olivae BRB18, B. licheniformis HT-26-B1, B. cereus H17, B. safensis MS40, B. pumilus 07.
\end{abstract}

\section{Keywords}

Cassava, PCR, Amylase, Hydrolysis, Bacillus

\section{Introduction}

Cheap and readily available agricultural waste such as cassava peels, which presently constitutes a menace to solid waste management, may be a rich source of amylolytic bacteria [1]. Though many microorganisms can grow on a wide range of carbon and nitrogen sources, it is economically more viable to utilize the 
cheap and easily available resources as substrates for amylase production [2]. Although plants and animals produce amylases, enzymes from microbial sources are generally used in industrial processes. This is due to a number of factors including higher productivity, thermostability of the enzyme as well as ease of cultivating microorganisms [3] [4].

Prominent among bacteria used in commercial production are the Bacillus sp. [5] [6] [7] [8]. Others, such as Escherichia sp., Pseudomonas, Proteus, Serratia and Rhizobium also yield appreciable quantity of the enzyme [9]. Aspergillus, Rhizopus, Mucor, Neurospora, Penicillium and Candida species are some of the fungi that also produce extracellular amylases of commercial value [7] [10]. Members of the genus Bacillus are heterogeneous and they are very versatile in their adaptability to the environment. Among the species of Bacillus, B. subtilis, B. stearothermophilus, B. amyloliquefaciens, B. licheniformis, B. acidocaldarius, Bifidobacterium bifidum and $B$. acerans are important species [11]. The $\alpha$-amylases from B. licheniformis, B. amyloliquefaciens and B. stearothermophilus are among the most widely studied amylases and are highly homologous with respect to primary and tertiary structure [12].

The development of ultra-high-throughput sequencing technologies has been instrumental in advancing research in all scientific areas but more particularly in Microbiology where the genomes are small [13]. Polymerase chain reaction (PCR) offers several advantages in identification as there has been a shift towards DNA-based protocols developed for diagnostic purposes as well as for etiological or epidemiological studies, as reported by some published reviews [14]-[21] as it is highly sensitive, relatively simple and fast to perform. Application of PCR techniques in diagnostic laboratories for routine purposes is also increasing and will continue in the near future, especially for the rapid screening of samples. A wide range of plant-pathogenic bacteria can be currently detected by PCR in numerous hosts or environmental samples [22]. In this study, we carried out molecular characterization using PCR on some amylolytic Bacillus species isolated from soils and peels obtained from cassava waste dump sites.

\section{Materials and Methods}

\subsection{Sample Collection and Bacterial Isolation}

Soil samples and peels from cassava waste dump sites were collected through aseptic measures from 2 different locations: a dumpsite near a gari processing factory in Oyo town, Oyo state, Nigeria and another from a dumpsite in Alaya village, Aiyedire local government, Osun state, Nigeria. The soil was collected 10 $\mathrm{cm}$ deep into the earth by digging and collected in aseptic plastic bagsas described by [23] and transported to the laboratory for immediate analysis. Sampling was carried out twice: during dry season (December, 2016) and early rainy season (March, 2017).

Bacterial isolation was done using the pour plate technique. Twenty grammes of each sample (peels and soil) was weighed and homogenized in $180 \mathrm{ml}$ saline 
solution in order to get 1:9 dilution. The mixture was shaken vigorously. One millilitre of the sample was serially diluted up to the 6th dilution [24] and the 5th and 6th dilutions was plated on nutrient agar and was incubated for 24 hours at $37^{\circ} \mathrm{C}$ in a Genlab INC/100 incubator. Pure cultures were kept as stock on slants of the requisite medium for further use later. Preliminary taxonomic characteristics of the isolated bacteria were determined by colony morphology, Grams staining, growth pattern and biochemical analysis (Hamid et al., 2003). More details on bacterial isolations and amylase activities have been previously described [25].

\subsection{DNA Extraction}

DNA extraction and sequencing was carried out with the assistance of technologists from International Institute of Tropical Agriculture (IITA), Ibadan, Oyo State, Nigeria. The genomic DNA of the isolate used in this research was extracted using QIAamp DNA mini kit (250) cat no 51,306 (manufactured by QIAGEN, Germany).

The procedure used for the DNA extraction was carried out following the instructions indicated in the manufacturers' kit. Absolute ethanol 2\% vol (20 $\mu \mathrm{l})$ was added to the samples product after which it was incubated at room temperature for 15 minutes. The product was centrifuged at 10,000 rpm for 15 minutes and supernatant was decanted. The supernatant was again centrifuged at 10,000 rpm for another 15 minutes. Afterwards, $2 \%$ vol. ( $40 \mu \mathrm{l})$ of $70 \%$ ethanol was added and decant of the supernatant was repeated. The product was air-dried and about $10 \mu \mathrm{l}$ of ultra-pure water was added. After the extraction, the DNA was subjected to a cocktail mix and condition for the PCR. Ultra-pure water (10 ul) was added. Concentrations of DNA were estimated using a nanodrop spectrophotometer (Jenway model 6305).

\subsection{PCR Amplification and Molecular Identification of Bacterial Isolate}

The 16s RNA gene was amplified by PCR using two universal primers. The forward primer being 27F: $5^{1}$-AGAGTTTGATCMTGGGTCAG- $3^{1}$ and the reverse primer 1525R: $5^{1}$-AAGGAGGTGWTCCARCCGCA- $3^{1}$. The thermal cycler was programmed and set at an initial denaturation at $94^{\circ} \mathrm{C}$ for 5 minutes, 36 number of cycles of denaturation at $94^{\circ} \mathrm{C}$ for 30 seconds, annealing at appropriate temperature of $56^{\circ} \mathrm{C}$ for 30 seconds and $72^{\circ} \mathrm{C}$ for 45 seconds and a final extension at $72^{\circ} \mathrm{C}$ for 7 minutes while the holding temperature was at $10^{\circ} \mathrm{C}$. The amplicon from the reaction above was loaded on $1.5 \%$ agarose gel and the gel picture is attached as PCR. The ladder used was $1 \mathrm{~kb}$ plus ladder from Invitrogen. The expected base pair of the amplicon was around $1500 \mathrm{bp}$. The PCR products were separated on $1.5 \%$ agarosegel.

Finally, the amplicon was checked on $1.5 \%$ agarose. The PCR product was used for the sequencing reaction. The forward and reverse sequencing primers 
were used to sequence the entire length of the double stranded DNA. The sequencing reaction was also purified. The product from the purification was loaded on the 3131xl gene analyzer from Applied Bio-systems to give the sequences. The sequences were then compared with already identified nucleotide sequences on National Center for Biotechnology Information (NCBI) GenBank database.

\section{Results and Discussion}

Determining the bacterial species is often crucial for making accurate decisions since this should provide direct information on the distinctive abilities of the microorganism [13]. A total of thirty-four organisms were isolated from peels and soil of cassava waste from the sample sites as described earlier by [25]. However fourteen organisms (which included the organisms with the maximum zone of clearance during starch hydrolysis) were randomly selected for the genetic sequencing. Table 1 shows the nanodrop readings of the extracted DNA from the spectrophotometer as the absorbance of purity of the sample falls mostly within the range of $1.6-2.14$ and also the concentration of the extracted DNA measured in $\mathrm{ng} / \mu \mathrm{l}$ ranging between 14.4 and $374 \mathrm{ng} / \mu \mathrm{l}$. The DNA molecular marker used during the agarose gel electrophoresis was $1 \mathrm{~kb}$ plus Invitrogen ladder which shows the concentration of the DNA and its level of amplification.

The identification process after the genetic sequencing shows that Bacillus subtilis (21.44\%) was the most frequently occurring specie, although, the Bacillus species were still further classified according to their varying strains while other isolates featured sporadically. Interestingly, the results also shows the prevalence of two similar strains B. subtilis MML2483 and B. subtilis MML2411 which was isolated from the different sampling sites. The abundance of Bacillus sp. as recorded during this study shows its dominance in the habitat of all the sampling sites. Research has shown that cassava peels and soil from cassava dumpsites which forms a nuisance to the community may well be converted to very useful raw materials in the industries [26] [27]. This study shows that some of the strains which are already identified due to their genetic sequences can be exploited for large scale production of amylase having shown a wide zone of clearance during starch hydrolysis (Plates 1-3).

Other bacterial strains identified included Bacillus olivae BR18, Sphingobacterium compostii NNBRC 106383, Entobacteriacaea bacterium G2-5, Y78, Bacillus subtilis SCSGA0128, Bacillus licheniformis HT-Z6-B1, Bacillus cereus H17, Bacillus safensis MS40, Lysinbacillus sphaericus RSEN1, Klebsiella pneumoniae T02 and Bacillus pumilus 07.

\section{Conclusion}

The research involving use of microorganisms to produce amylolytic enzymes is increasing daily and the need to explore more of their potentials cannot be overstated. The results show that for wider industrial applications, genetic studies is 
Table 1. Nanodrop spectrophotometer readings of extracted DNA.

\begin{tabular}{cccc}
\hline S/N & Sample ID & Nucleic acid $(\mathrm{ng} / \mu \mathrm{l})$ & $260 / 280$ (\% ratio) \\
\hline 1 & Sample 1 & 14.4 & 1.9 \\
2 & Sample 2 & 25.3 & 1.73 \\
3 & Sample 3 & 56.2 & 2.04 \\
4 & Sample 4 & 254.7 & 2.04 \\
5 & Sample 5 & 33.7 & 1.98 \\
6 & Sample 6 & 69.7 & 1.55 \\
7 & Sample 7 & 66.3 & 1.77 \\
8 & Sample 8 & 85.9 & 2.03 \\
9 & Sample 9 & 100.2 & 1.68 \\
10 & Sample 10 & 62.8 & 1.78 \\
11 & Sample 11 & 186.6 & 2.14 \\
12 & Sample 12 & 374.4 & 1.97 \\
13 & Sample 13 & 23.9 & 1.6 \\
14 & Sample 14 & 120.2 & 1.93 \\
\hline
\end{tabular}

$\begin{array}{llllllllllllll}1 & 2 & 3 & 4 & 5 & 6 & 7 & 8 & 9 & 10 & 11 & 12 & 13 & 14\end{array}$

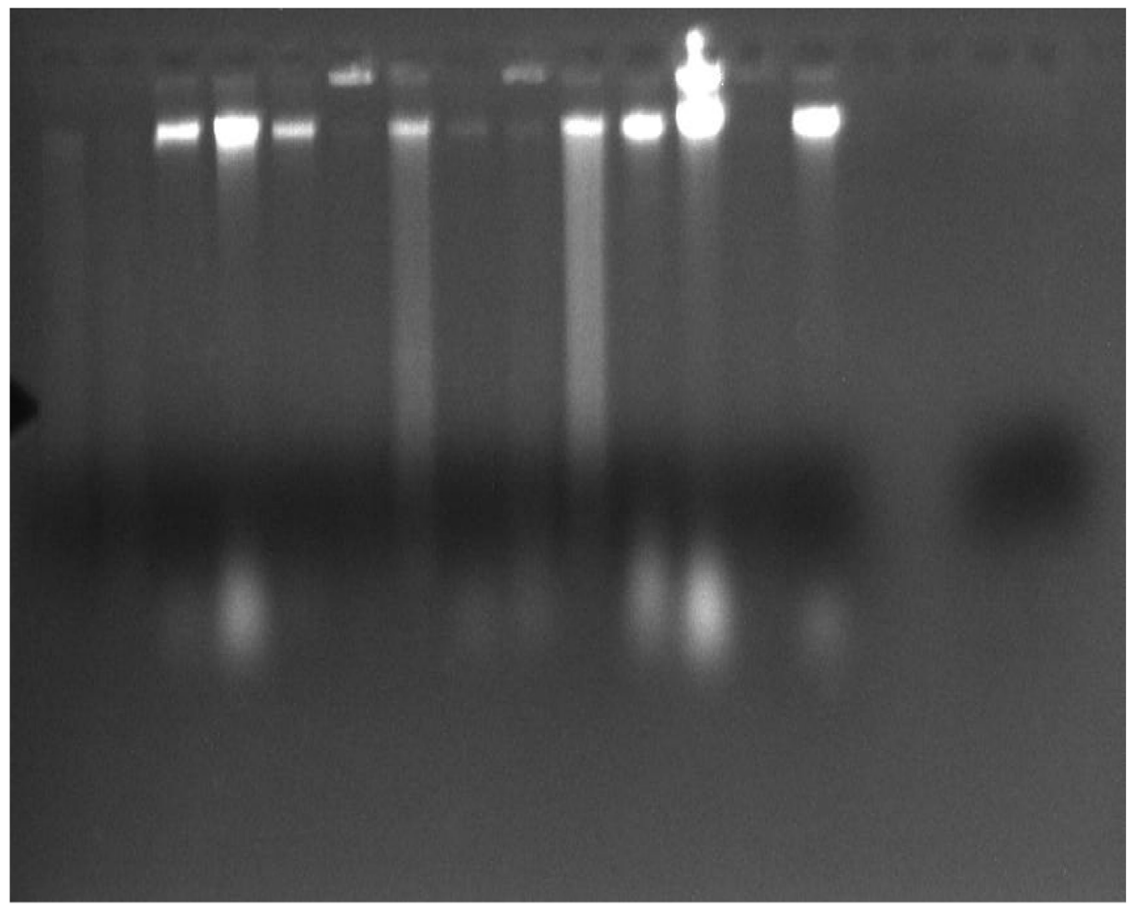

Plate 1. Agarose gel electrophesis of amplified DNA extracted from the isolated bacteria (Lane 1: B. olivae BRB18, Lane 2: B. subtilis MML2483, Lane 3: Sphingobacterium compostii NNBRC 106383, Lane 4: Enterobacteriaceae bacterium G2-5, Lane 5: Acinetobacter baumanii Y78, Lane 6: B. subtilis SCSGAB0128, Lane 7: B. licheniformis HT-Z6-BI, Lane 8: B. cereus H17, Lane 9: B. safensis MS40, Lane 10: B. subtilis MML2411, Lane 11: Lysinbacillus sphaericus RSENI, Lane 12: Klebsiella pneumonia T02, Lane 13: B. pumilus 07, Lane 14: Unidentified). 


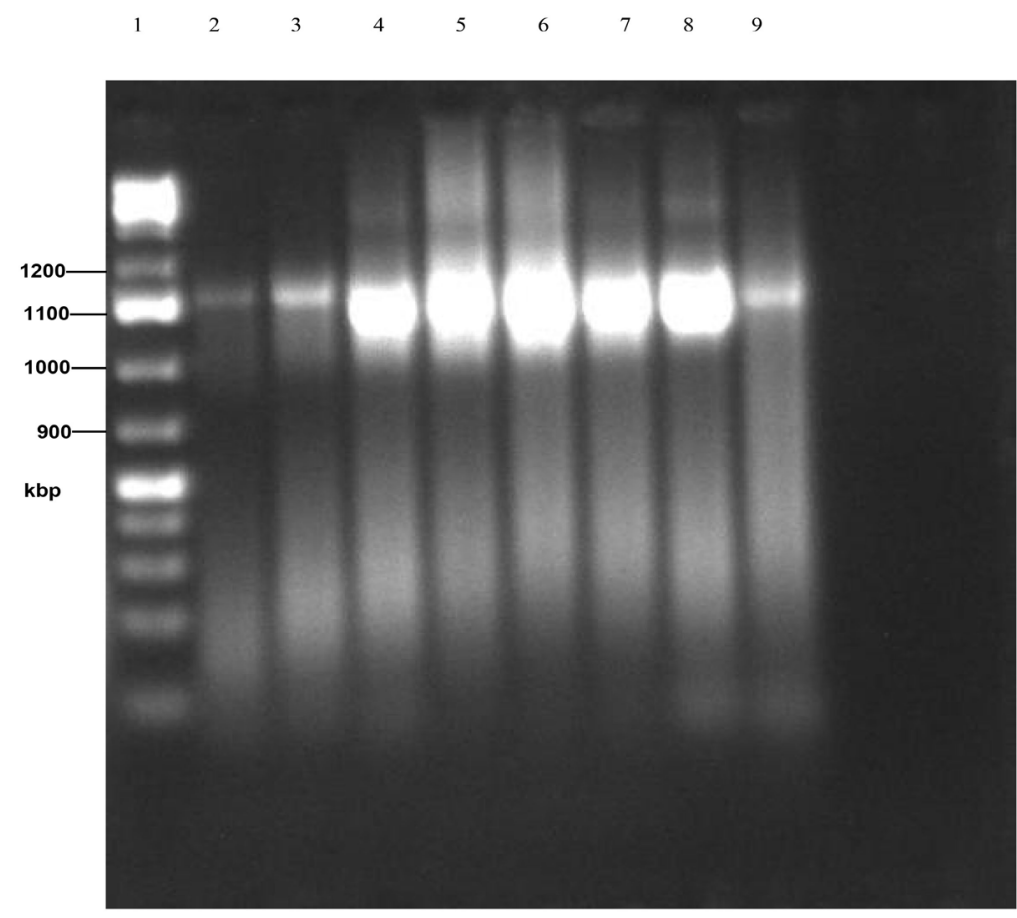

Plate 2. PCR gel electrophoresis of amplified 16sRNA of isolates 1 - 8. (Lane 1: Marker, Lane 2: B. olivae BRB18, Lane 3: B. subtilis MML2483, Lane 4: Sphingobacterium compostii NNBRC106383, Lane 5: Enterobacteriaceae bacterium G2-5, Lane 6: Acinetobacter baumanii Y78, Lane 7: B. subtilis SCSGAB0128, Lane 8: B. licheniformis HT-Z6-BI, Lane 9: B. cereus $\mathrm{H} 17)$.

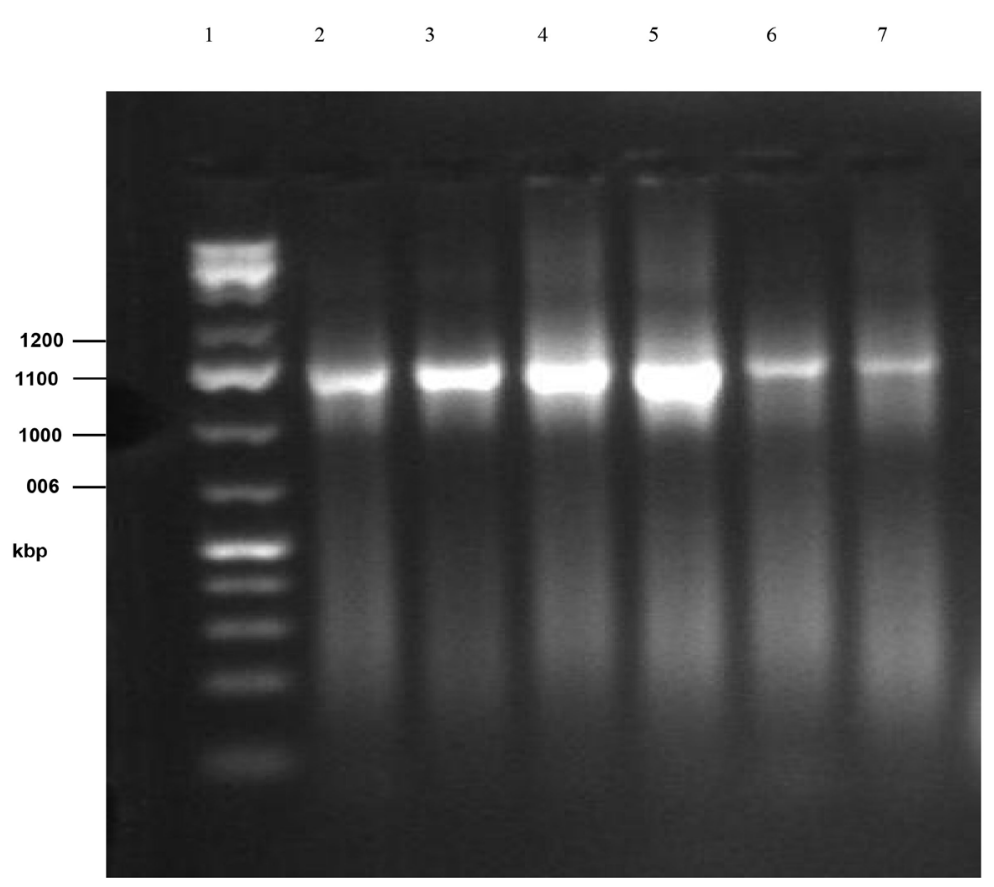

Plate 3. PCR gel electrophoresis of amplified 16sRNA of isolates 9 - 14 (cont'd.) (Lane 1: Marker, Lane 2:B. safensis MS40, Lane 3: B. subtilis MML2411, Lane 4: Lysinbacillus sphaericus RSENI, Lane 5: Klebsiella pneumonia T02, Lane 6: $B$. pumilus 07, Lane 7: Unidentified). 
needed to manipulate the organisms for better amylase production as the best producing strains will be more easily identified and closely observed and produced en-mass while maintaining the conditions for their growth and survival in keeping their stock.

\section{Acknowledgements}

Author wishes to acknowledge all staff at the Bioscience Laboratory of International Institute of Tropical Agriculture (IITA), Ibadan, Oyo State, Nigeria for helping with the necessary laboratory facilities and assistance in carrying out polymerase chain reaction procedures.

\section{Author's Contributions}

Ayansina, A.D.V. is the major supervisor of the work. He and Adelaja, A.O. did $90 \%$ of the practical procedures of the work. Baba, J. supplied some literature information used and read through for correctness.

\section{Conflicts of Interest}

The authors declare no conflict of interest in this work.

\section{References}

[1] Ali, S., Mahmood, S., Alan, R. and Hossain, Z. (1998) Culture Conditions for Production of Glucoamylase from Rice bran by Aspergillus cerreus. MIRCEN Journal of Applied Microbiology and Biotechnology, 5, 525-532. https://doi.org/10.1007/BF01741829

[2] Pandey, A., Soccol, C.R., Nigam, P. and Soccol, V.T. (2000) Biotechnological Potentials of Agro-Industrial Residues II: Cassava Baggase. Bioresource Technology, 74, 68-80.

[3] Odee, D.W., Sutherland, J.M., Makatiani, E.T., Mclonroy, S.G. and Sprent, J.I. (1997) Phenotypic Characteristics and Composition of Rhizobia Associated with Woody Legumes Growing in Diverse Kenyan Conditions. Plants and Soils, 188, 65-75. https://doi.org/10.1023/A:1004204413140

[4] Reddy, R.R.M., Reddy, G. and Seenayya, G. (1999) Enhanced Production of Thermostable-Amylase of Pullulunase in the Presence of Surfactants by Clostridium thermosulfurogenes SV2. Process Biochemistry, 34, 87-92.

https://doi.org/10.1016/S0032-9592(98)00073-9

[5] Amund, O.O. and Ogunsina, O.A. (1987) Amylase Producing Bacterial Strains Associated with Cassava Fermentation. Journal of Industrial Microbiology \& Biotechnology, 2, 123-127.

[6] Olafimihan, C.A. and Akinyanju, J.A. (1999) Thermophilic Amylase Producers from the Soil. Nigerian Journal of Pure and Applied Sciences, 14, 816-822.

[7] Pandey, A., Nigam, P., Soccol, C.R., Soccol, V.T., Singh, D. and Mohan, R. (2000) Advances in Microbial Amylases. Biotechnology and Applied Biochemistry, 31, 135-152. https://doi.org/10.1042/BA19990073

[8] Gupta, R., Cigras, P., Mohapatra, K., Goswami, V.K. and Chauhan, B. (2003) Microbial-Complex in Detection of Higher Oligosaccharides on Paper. Current Science, 59, 1339-1340. 
[9] Oliviera, A.N., Oliviera, L.A., Andrade, J.S. and Chagas, A.F. (2007) Rhizobial Amylase Production Using Various Starchy Substances as Carbon Sources. Brazilian Journal of Microbiology, 38, 208-214.

[10] Gupta, R., Gigras, P., Mohapatra, H., Goswami, V.K. and Chauhan, B. (2003) Amylase: A Biotechnological Perspective. Biotechnology Progress, 38, 1599-1616. https://doi.org/10.1016/S0032-9592(03)00053-0

[11] Rohban, R., Amoozegar, M.A. and Ventosa, A. (2008) Screening and Isolation of Halophilic Bacteria Producing Extracellular Hydrolyses from Howz Soltan Lake. Journal of Industrial Microbiology \& Biotechnology, 36, 333-340. https://doi.org/10.1007/s10295-008-0500-0

[12] Nielsen, A.D., Pusey, M.L., Fulsgang, C.C. and Westh, P. (2003) A Proposed Mechanism for the Thermal Denaturation of a Recombinant Bacillus halmapalus Amylase: The Effect of Calcium Ions. Biochimica et Biophysica Acta, 1652, 52-63. https://doi.org/10.1016/j.bbapap.2003.08.002

[13] Greub, G. and Bertelli, C. (2013) Rapid Bacterial Genome Sequencing, Methods and Application in Clinical Microbiology. Clinical Microbiology and Infection, 19, 803-813. https://doi.org/10.1111/1469-0691.12217

[14] Henson, J.M. and French, R. (1993) The Polymerase Chain Reaction and Plant Disease Diagnosis. Annual Review of Phytopathology, 31, 81-109. https://doi.org/10.1146/annurev.py.31.090193.000501

[15] Louws, F.J., Rademaker, J.L.K. and De Bruijn, F.J. (1999) The Three DS of PCRBased Genomic Analysis of Phytobacteria, Diversity, Detection, and Diagnosis. Annual Review of Phytopathology, 37, 81-125. https://doi.org/10.1146/annurev.phyto.37.1.81

[16] López, M.M., Bertolini, E., Olmos, A., Caruso, P., Gorris, M.T., Llop, P., Penyalver, R. and Cambra, M. (2003) Innovative Tools for Detection of Plant Pathogenic Viruses and Bacteria. International Journal of Microbiology, 6, 233-243. https://doi.org/10.1007/s10123-003-0143-y

[17] Schaad, N.W., Frederick, R.D., Shaw, J., Schneider, W.L., Hickson, R., Petrillo, M.D. and Luster, D.G. (2003) Advances in Molecular-Based Diagnostics in Meeting Crop Biosecurity and Phytosanitary Issues. Annual Review of Phytopathology, 41, 305-324. https://doi.org/10.1146/annurev.phyto.41.052002.095435

[18] Alvarez, A.M. (2004) Integrated Approaches for Detection of Plant Pathogenic Bacteria and Diagnosis of Bacterial Diseases. Annual Review of Phytopathology, 42, 339-366. https://doi.org/10.1146/annurev.phyto.42.040803.140329

[19] López, M.M., Bertolini, E., Marco-Noales, E., Llop, P. and Cambra, M. (2006) Update on Molecular Tools for Detection of Plant Pathogenic Bacteria and Viruses. In: Rao, J.R., Fleming, C.C. and Moore, J.E., Eds., Molecular Diagnostics, Current Technologies and Applications, Horizon Bioscience, Norfolk, 1-46.

[20] Vincelli, P. and Tisserat, N. (2008) Nucleic Acid-Based Pathogen Detection in Applied Plant Pathology. Plant Disease, 92, 660-669.

https://doi.org/10.1094/PDIS-92-5-0660

[21] López, M.M., Llop, M.P., Olmos, A., Marco-Noales, E., Cambra, M. and Bertolini, E. (2009) Are Molecular Tools Solving the Challenge Posed by Detection of Plant Pathogenic Bacteria and Viruses? Current Issues in Molecular Biology, 11, 13-46.

[22] Schaad, N.W., Jones, J.B. and Chun, W. (2001) Laboratory Guide for Identification of Plant Pathogenic Bacteria. 3rd Edition, APS Press, St. Paul.

[23] Shivaji, S., Pratibha, M.S., Sailaja, B., Har-Kishore, K., Singh, A.K., Begum, Z., Anarasi, U., Prabagaran, S.R., Reddy, G.S. and Srinivas, T.N. (2011) Bacterial Diversity 
of Soil in the Vicinity of Pindari Glacier, Himalayan Mountain Ranges, India, Using Culturable Bacteria and Soil 16S rRNA Gene Clones. Extremophiles, 15, 1-22. https://doi.org/10.1007/s00792-010-0333-4

[24] Harrigan, W.F. and McCance, E.M. (1966) Laboratory Methods in Microbiology. Academic Press, Vol. 54, 970.

[25] Ayansina, A.D.V., Adelaja, A.O. and Mohammed, S.S.D. (2017) Characterization of Amylase from Some Aspergillus and Bacillus Species Associated with Cassava Waste Peels. Advances in Microbiology, 7, Article ID: 75659.

https://doi.org/10.4236/aim.2017.74023

[26] Aderemi, F. (2010) Utilization of Graded Levels of Biodegraded Cassava Peels in Broiler Ration. Electronic Journal of Environmental, Agricultural and Food Chemistry, 9, 672-678.

[27] Ayansina, A.D.V., Adebola, M.A. and Adeyemi, A.O. (2014) Some Microorganisms Associated with Soils Exposed to Cassava (Manihot eduttasculatum) Peels. American Journal of Research Communication, 2, 155-162. 